\title{
How Eurosceptic is Fidesz actually?
}

\author{
Tibor Hargitai
}

\section{sciendo}

Politics in Central Europe (ISSN: 1801-3422)

Vol. 16, No. 1

DOI: 10.2478/pce-2020-0009

\begin{abstract}
Until now there is no consensus in the academic literature as to whether Fidesz is a (soft) Eurosceptic party or rather Europragmatic. By identifying the manifestations of Euroscepticism on the policy level rather than the party level, this article sheds light on the dynamics of Fidesz's Euroscepticism. It also looks at the party strategy of Fidesz regarding its main Eurosceptic competitor Jobbik, and how this facilitated further Euroscepticism. Hungary's vision of the EU is at odds with the vision of most member states and EU institutions, which makes Fidesz not only Eurosceptic; but there is a form of inverted soft Euroscepticism characterising Fidesz's vision and policies towards the EU.
\end{abstract}

Keywords: party-based Euroscepticism, EU policies, Fidesz, Jobbik, contagion, accommodative strategy Hungary

\section{Introduction}

The ruling party in Hungary since 2010 is Fidesz ${ }^{1}$. Their rule has since then remained virtually unchallenged nationally; although the municipal elections of October 2019 mark a notable change in cities across the country, where opposition politicians won. Across Europe there has been much criticism on the way Fidesz governs Hungary, and on its attitude towards the European Union (EU). These are two different things though. Democratic backsliding (see for instance Ágy 2013; Sedelmeier 2014; Kochenov and Bárd 2018; Procházka and Cabada 2020) does not have to imply a Eurosceptic attitude towards the EU. Nonethe-

1 Officially Fidesz-KDNP. However, Fidesz-KDNP is considered to be one party, since the KDNP has been in a permanent alliance with Fidesz since 2006, and KDNP did not make it into the Parliament the last time they ran on their own, receiving $3.9 \%$ of the votes in 2002 , below the $5 \%$ threshold. 
less, it was Fidesz's political decision-making that led it to be suspended from its own European party group, the European People's Party (EPP) (Thorpe 2019). At the same time, much of Fidesz's criticism directed at the European Union seems to be rhetorical in nature. But how Eurosceptic is Hungary's ruling party actually? The purpose of this paper is to offer an answer to that question; it does so by reviewing attitudinal and substantive manifestations of Euroscepticism.

Firstly, the academic debate on whether Fidesz is Eurosceptic or not serves as the basis of the argument. Secondly, the vision of the Hungarian government party on the EU is captured, which illuminates the party's position on the EU. In order to capture the actual positions of the party, the third section discusses the specific policy areas in which Fidesz is Eurosceptic. Fourthly, Jobbik is added to the equation and the section looks at how Fidesz has adopted an accommodative party strategy to weaken Jobbik. Lastly, the paper reflects on the notion of 'inverted soft Euroscepticism'.

\section{The academic debate on the Euroscepticism of Fidesz}

There is no clear consensus in the academic literature on whether Fidesz is a (soft) Eurosceptic party, or rather Europragmatic. ${ }^{2}$ On the one hand, Batory (2008) classifies Fidesz in the period 2002-2006 as soft Eurosceptic. She argues that during the campaign in the wake of Hungary's accession to the EU, Fidesz positioned itself strategically between the pro-EU parties (MSZP and SZDSZ) and the hard Eurosceptic Hungarian Justice and Life Party (MIÉP). Fidesz campaigned in favour of EU accession, but 'it was... a "yes, but" stance that characterised Fidesz politicians' statements in the run-up to the referendum on EU membership' (Ibid.: 272).

The focus on the national interest comes back in Fidesz' election programme of 2006, where the party focuses specifically on economic convergence with Western Europe, and emphasises the need to strengthen security and 'the need to strengthen the representation of the interests of the Hungarians in all areas' (Fidesz 2006: 38). Furthermore, Fidesz emphasises that the 'Hungarian people have made great sacrifices to become an EU member' (Ibid.: 37 ) and it is the government's task to ensure they experience the benefits of membership. That

2 There is a lengthy debate in this same literature as to what party-based Euroscepticism constitutes and how it should be measured (see for instance Szczerbiak and Taggart 2018); however, for the purpose of this paper Taggart and Szczerbiak's distinction of soft and hard Euroscepticism will be used.

Hard Euroscepticism: 'there is a principled opposition to the EU or the European integration and therefore can be seen in parties who think that their countries should withdraw from membership, or whose policies towards the EU are tantamount to being opposed to the whole project of European integration as it is currently conceived' (Taggart and Szczerbiak 2008a:. 7).

Soft Euroscepticism: 'there is not a principled objection to European integration or EU membership but where concerns on one (or a number) of policy areas lead to the expression of qualified opposition to the EU, or where there is a sense that "national interest" is currently at odds with the EU"s trajectory' (Taggart and Szczerbiak 2008a: 8). 
said, Fidesz does not take a clear Eurosceptic in 2006. Nonetheless, Batory observes that Fidesz adopted a political strategy where it 'made its support for EU-related constitutional amendments conditional upon the government's acceptance of part of its own economic programme, which they saw as essential for Hungary's preparation for accession' (2008: 271).

Enyedi (2006, in Várnagy 2013) considers Fidesz to be a party that uses populist rhetoric towards the EU, yet had a relatively pro-European, albeit less visible, Euromanifesto in 2004. Várnagy (2013) similarly finds that Fidesz was moderate in its criticism towards the EU during the 2009 EP elections and directed its criticism mostly towards the national government, in anticipation of its electoral victory in 2010.

Furthermore, Duró does not consider Fidesz to be a Eurosceptic party after 2010 either, because it continues to have a 'clear pro-European policy in practice, i.e. it has always supported the deepening of the European integration' (2016: 44). He goes on to say that the confrontational rhetoric of Fidesz is a consequence of the sizeable share of Eurosceptic voters in Hungary. Similarly, Treib (2014) does not add Fidesz to the list of Eurosceptic parties in the European Parliament after the 2014 EP elections.

On the other hand, looking at Fidesz in office since 2010, Taggart and Szczerbiak (2013) highlight that Fidesz continued to be a soft Eurosceptic party and that the party feels immune to criticism on EU policy since its large electoral victory in 2010, although Jobbik has been considered a strategic competitor on several policy areas. In fact, there has been a notable convergence of policy positions between far-right Jobbik and Fidesz. While Jobbik has moderated its position towards the EU since 2014, and stopped striving for an EU-exit of Hungary, Fidesz's position has become more critical towards the EU (Enyedi and Róna 2018).

All in all, there is an ambiguity as regards the Euroscepticism of the party that has been in power in Hungary since 2010. In the absence of a party manifesto by Fidesz(-KDNP) for the 2014 and 2018 elections, survey data by Göncz and Lengyel provide insights regarding the position of Fidesz on European integration. Göncz and Lengyel (2016) surveyed members of the Hungarian Parliament, and their findings show that Fidesz became more focused on intergovernmentalism between 2007 and 2014. However, in 2007, Fidesz was already much more inclined towards intergovernmentalism as compared to the average in the Hungarian parliament. Furthermore, for Fidesz competitiveness is considered the main aim of the EU, which over time has become relatively more important than the social dimension. Despite these changes, the attachment to Europe remained virtually unchanged between 2007 and 2014.

What follows are the visions, or strategies, of Fidesz towards the European Union. The attitude of the party is far from straightforward, but there are recurring themes that help understand Fidesz's approach towards the EU. 


\section{Visions of the European Union}

A good starting point for the analysis of Fidesz's EU vision is the 15 March 2016 speech of Prime Minister Orbán on the occasion of the commemoration of the 1848 Revolution. In his speech Orbán depicts the EU to be unfree and 'fragile, weak and sickly as a flower being eaten away by a hidden worm' (Orbán 2016). The Prime Minister argues that Europe is not free, because 'it is forbidden to speak the truth' about how the majority of the actors in the EU are 'constructing schemes to transport foreigners here as quickly as possible and to settle them here among us' (Ibid.). He goes on to say that mass migration is used 'to redraw the religious and cultural map of Europe and to reconfigure its ethnic foundations, thereby eliminating nation states, which are the last obstacle to the international movement'. He added that the current policies of the EU pose an existential threat to the survival of the continent as it has been known, therefore the 'anti-immigration' forces need to be in the majority in EU institutions.

A second critique of Fidesz towards the EU is the transfer of competences. During the same speech in 2016, Prime Minister Orbán's attacks how 'Brussels is stealthily devouring ever more slices of our national sovereignty, and that in Brussels today many are working on a plan for a United States of Europe, for which no one has ever given authorisation'. The EU's threat to Hungary's national sovereignty is a recurring theme in the rhetoric of Fidesz. Also former Foreign Minister János Martonyi (2010-2014) refers to the 'creeping transfer of power from the member states to the Union', which follows from the self-interest of the 'rival common institutions' (Martonyi 2014: 362) - the European Commission and European Parliament. Thirdly, the national consultation in April 2017 entitled 'Let's Stop Brussels' was dedicated specifically to that issue.

National consultations in Hungary are devices used to sway voters into believing they have a direct say on the future of the country regarding major domestic issues. Prior to a national consultation, every Hungarian citizen receives a letter from the government explaining the motivation for the Consultation. In April 2017, the letter said that: 'The title of the consultation perfectly expresses the position we represent: Let's stop Brussels! Let's stop the appropriation of national powers by Brussels! Let's stop Brussels' policy of continually seeking to exceed the powers given to it in the Treaties! And let's stop efforts which - through the promotion of migration - seek to change the ethnic composition and cultural foundations of the European Union, and Hungary within it!' (Government of Hungary 2017). However, while the EU has outstepped its competences, the Hungarian government defends itself as being pro-European: 'The European Commission has called the Government of Hungary anti-European. This is either a misconception or a malicious political attack. Hungary is on the side of Europe, it works for a strong Europe, and wishes to reform the policies pursued in Brussels so that Europe can remain the best place in the world. Europe must 
put an end to terrorism, regain its security, and once again become competitive in the world economy. Through a common foreign and security policy it must deliver peace and stability to the surrounding regions, including Ukraine and the Balkans' (Ibid.).

It is this ambiguous attitude towards the EU - in favour of transfers of competences back to the member state coupled with a mocking rhetoric towards actors in the EU on the one hand, and reaffirming the commitment towards a strong EU on the other hand - that Fidesz uses to manoeuvre itself through the European institutions, and in the national and foreign press. By framing the critique of democratic backsliding in Hungary as a critique against the Hungarian people, Fidesz fosters nationalist sentiments among voters: 'the people... gave good advice, good command to the Hungarian Parliament [for adopting the basic law], which it carried out. In this sense, when the Hungarian constitution is criticized... it is not meant for the government but for the Hungarian people... It is not the government the European Union has a problem with, much as they want us to believe..., the truth is they attack Hungary' (Orbán (2013) quoted in Batory 2015: 8). Such statements of Fidesz/Orbán are populist in nature, whereby the corrupt elite acts against the will of the people (Csehi 2019).

According to Fidesz, the transfer of competences to the EU puts the European institutions against the will of the people. Therefore, Fidesz cautions for the risk of a 'continuous rise in the popularity of radical, extremist political forces outside the current mainstream' that can follow from the 'widening gap between European leaders and the common sense of the European people' (Orbán 2015b). The same tactic was used in 2018, when Fidesz argued that the Sargentini report was an attack against the Hungarian people.

An earlier report of the European Parliament that scrutinised the rule of law in Hungary was the Tavares Report in 2012. It mostly investigated the new Constitution of 2011, amendments to the Constitutional Court's structure and controversial changes to the media law. In response to the adoption of Resolution 2012/2130(INI) in the European Parliament in July 2013, a senior member of Fidesz declared that ' $[w]$ e Hungarians no longer want a Europe where freedom is restricted and not complete. We no longer want a Europe where the larger [member states] abuse their power, where the sovereignty of nations is violated, and where only the smaller ones have to respect the larger [members]' (Rogán - Gulyás - Kocsis 2013). The Fidesz party defends its position against criticism from other member states or by Members of the European Parliament or the European Commission as attacks against the sovereignty of Hungary.

A third tactic, or rhetorical device, of the ruling party in Hungary has been to express its critical approach on the content of the EU while leaving the structure intact. An example of this was in the wake of the European Parliament elections of 2019, when Prime Minister Viktor Orbán highlighted that Fidesz has two goals related to the EU it wants to achieve with the elections. 'It is Hungary's goal 
for anti-immigration forces to be in the majority in every institution within the European Union's institutional system... Our second goal is to be - as has been the case in the past - the most successful party in Europe; but at all events we want to be the most successful within the European People's Party' (Orbán 2019a). Here, Orbán does not go into how the EU itself is problematic, but that the composition of the institutions is what has to change.

The fourth, and last, tactic focuses on the structural EU funds of which Hungary is the largest net beneficiary. During the first phases of the negotiations of the Multi-Annual Financial Framework (MFF) for the period of 2021-2027 the MFF is the EU's budget for a period of seven years - the idea has been to condition receiving the structural funds on the rule of law. This has been condemned by the Hungarian government, on the grounds that there are enough mechanisms in place to safeguard the rule of law (Than 2019). The government considers the EU funds to be a right that should not be challenged. When, at the height of the migration crisis, there was a debate about whether EU funds might be conditioned on cooperating with the migrant quota scheme, Prime Minister Orbán argued that he does not see EU funds as aid from Western Europe, but as what is means to be 'part of a common economic zone' (Orbán 2015a). The Hungarian government thus frames the fact that Hungary receives such high EU funds as payback for the opportunities it missed for economic development under communism (Ibid.). This is a way of framing the structural funds much at odds with those countries that support the rule of law conditionality.

Beyond these visions of the EU, what are the actual policy positions of Fidesz, and which are Eurosceptic, if any?

\section{Party-Euroscepticism in the policy level}

In order to clarify the uncertainty around Fidesz's Euroscepticism, this article will use a more fine-grained approach of party-based Euroscepticism by looking at the manifestations of Euroscepticism on the policy level (Hargitai 2018). It is easily imaginable that a party is in favour of deeper integration in the field of environmental policy but rejects the idea of a European army; or a party is against the common migration policy, but favours the further enlargement of the EU (the opposite also holds true). For this reason, the unit of analysis is not the party, but the party's position in a policy area. Not 'is Party A Eurosceptic?', but 'does Party A have a Eurosceptic position regarding policy XY?'. A Eurosceptic position is then one that rejects deeper and/or wider EU cooperation and/or an increased influence of a supranational institution like the European Commission.

A further specification of Euroscepticism on a policy level is Taggart and Szczerbiak's definition of Euroscepticism. For those authors soft Euroscepticism means 'where concerns on one (or a number) of policy areas leads to the expression of qualified opposition to the EU, or where there is a sense that 
„national interest“ is currently at odds with the EU trajectory' (2002: 4). Opposition to current EU trajectory is an assumption the authors make, so 'if someone supports the EU as it currently exists and opposes any further integration, that they are effectively Eurosceptic because this is at odds with what is the dominant mode of integration that is on-going' (Ibid.: 4). The idea of the current EU trajectory being at odds with the party's view of the national interest can also be considered on the policy level.

While I use the notion of the national interest being at odds with the current EU trajectory, it should be noted that Szczerbiak and Taggart later re-evaluated that element of their definition in 2008, and deem it to be over-inclusive. Be that as it may, for the purpose of testing whether Fidesz should be considered Eurosceptic, the party's conception of whether the EU's current trajectory goes against Hungary's national interest should be part of the discussion. I am thus aware of the fact that the notion is considered to be over-inclusive even by the authors that added it to their definition back in 2002, but including it does help to understand the party's position more accurately.

A second point of reflection from Taggart and Szczerbiak is in response to a criticism termed by Kopecký and Mudde (2002) as 'phoney Europhilia'. Kopecký and Mudde (2002) argue that the definition of soft Euroscepticism might be too broad, and that it might include parties that are proponents of European integration. Taggart and Szczerbiak's reasoning for including those parties nonetheless is based on the above-mentioned 'phoney Europhilia': there are parties 'that endorse EU membership for strategic reasons and claimed to be pro-EU membership in principle but whose actions and underlying values suggested a fundamental hostility to the European integration project' (2008: 242). Such an attitude would undermine the European integration project that could be Eurosceptic in nature.

Since the focus here is on a more specific unit of analysis than the party, there is no need to find the correct label of Euroscepticism to describe the party, but it will suffice to qualify a policy position to be Eurosceptic or not. A discussion of the policy areas where Fidesz has a Eurosceptic position follows.

Firstly, and hardly surprisingly, Fidesz is in favour of a transfer back of competences in the area of migration. During an annual speech at a summer camp in Transylvania, Prime Minister Orbán stated that 'the Commission must withdraw from the question of migration. It must create a council of interior ministers from the Schengen Area Member States, just as there is already a council of finance ministers from the eurozone countries. And all powers and responsibilities related to migration must be redirected to this council of interior ministers' (Orbán 2019b). Elsewhere, Fidesz positioned itself against cooperation in tackling migration on the European level, since 'Brussels has already decided to also launch resettlement programmes with no upper limit on numbers' (Government of Hungary 2017: 3). In fact, much of Fidesz's election 
campaign during the national elections in 2018 and the EP elections in 2019 focused on stopping migration and campaigning against the burden-sharing agreement proposed by the European Commission in 2015, and passed by the European Council later that year.

Secondly, on the establishment of an Energy Union. The Hungarian government highlights the threat of increased utility prices, if it would begin to abandon regulated pricing. This is at odds with the policy of Fidesz, because ' $[\mathrm{t}]$ his would again favour multinational corporations over Hungarian families' (Ibid. 2). Also, the Hungarian government lashed out against the European Commission's proposal of an Energy Union, because it would compromise Hungary's national sovereignty (Gotev 2015).

In terms of employment policy and fiscal policy, which are national competences, Fidesz argues that the European Commission has 'attacked' Hungarian national policies; and it is those attacks that strengthen the desire for keeping these policy areas national (Government of Hungary 2017).

Fifth, Fidesz opposes the creation of a European Public Prosecutor's Office (EPPO). On 30 October 2018, 100\% of the Fidesz MPs voted against the proposal to join the EPPO. In April 2019, the State Secretary of Justice, in a reply to a written question from MP Bertalan Tóth (MSZP, Socialists) on the topic, stated that the opposition to the EPPO is 'a matter of sovereignty' and that the Commission seeks 'more power at the expense of the Member States' (Völner 2019).

Beyond the above five policy areas where Fidesz holds an unambiguous position on European integration, a policy area where the qualification of party-based Euroscepticism requires further explanation is the Common Foreign and Security Policy (CFSP). Back in 2012, in its National Security Strategy, the Hungarian government stated itself to be a strong proponent of a strong EU through the CFSP (Ministry of Foreign Affairs of Hungary, 2012). Their actual policies may, however, work against exactly that.

The Treaty text helps to illustrate the point. Article 24(3) of the Treaty of the European Union states that 'Member States shall support the Union's external and security policy actively and unreservedly in a spirit of loyalty and mutual solidarity and shall comply with the Union's action in this area' (European Commission 2010). This article expresses the expectations enshrined in the Treaty regarding the level of commitment from member states to CFSP, even though they are frequently disregarded (Keukeleire - Delreux 2014). Nonetheless, single member states might prevent the EU from speaking with one voice, and thus hinder the support of 'the Union's external and security policy actively and unreservedly in the spirit of loyalty and mutual solidarity'.

On this basis, Fidesz's Russia and China policy can be said to be acts of Euroscepticism. Prime Minister Orbán was opposed to sanctioning Russia and continues to be opposed to the sanctions that were imposed following Russia's annexation of the Crimea in 2014 (BBC 2014; France24 2014), despite 
voting in favour of sanctions in the European Council. The natural gas deal between Hungary and Russia and a large Russian investment into the construction of a nuclear power plant in Hungary are considered controversial issues that 'destabilise the EU' (Gricius 2019). Odenstein and Kelemen (2016) consider Hungary to be one of the Trojan horses of Russia within the EU, that serve Russian interests and that undermine the functioning of CFSP.

Fidesz has a similar pragmatism towards China, which compromises the effectiveness of CFSP, being the government of the only EU member state that did not sign the joint statement denouncing China's Belt and Road Initiative for hampering free trade (Elmer 2018). The government puts the national interest above all else and 'shall not accept any kind of external ideological pressure' (Government of Hungary 2019a).

These attitudes are echoed in the findings of the European Council of Foreign Relations' (ECFR) Coalition Explorer. The Coalition Explorer is an expert survey on the attitudes towards European integration and coalition formation within the EU. The Hungarian government is shown to pursue policies towards Russia and China that strongly deviate from the policy preferences of almost all other member states. More than half of the experts indicated that Hungary prefers a solely national policy for China, Russia and the United States, while all the other member states even prefer cooperation on an informal group level the only exception being Poland's preference to a national policy towards the United States (ECFR 2018).

This strategic positioning of Fidesz within CFSP is here considered to be Eurosceptic. The party embraces the overall aim of CFSP but subsequently acts against an effective execution of the CFSP by opposing the position of the majority of the EU member states on issues related to Russia and China. This contrasts with other policy areas, where the Hungarian government openly declares their preferences against further European integration. While it is true that the CFSP is an intergovernmental domain and therefore a deviating position does not go against European integration, such a position can still be considered Eurosceptic, in that it departs from TEU article 24(3)'s 'spirit of loyalty and mutual solidarity'. More generally, Hungary is the least committed of the member states to deeper integration (ECFR 2018).

\section{Back to the definition}

When applying Taggart and Szczerbiak's 2002 definition of soft Euroscepticism, which includes the 'current EU trajectory being at odds with the national interest', Fidesz's overall attitude towards the EU is rather at odds with the interests of the majority of the member states, which makes for a kind of inverted soft Euroscepticism. That similarly holds true for the democratic developments in Hungary, to which the overwhelming vote in favour of the Sargentini Report 
in $2018^{3}$ would attest. They imply that the trajectory of Fidesz is at odds with that (of the rest) of the EU.

While this sounds like an interesting concept, its relevance should be carefully considered. Szczerbiak and Taggart (2008) decided to reject these kinds of critics of the EU since any party, no matter how pro-European, would be able to use such Eurocritical language at times. Pro-European parties make critical statements about the current functioning of the EU, directing their criticism for instance - at the lack of democratic accountability, which they might want to solve with the direct election of the President of the European Commission. For the evaluation of policy-level Euroscepticism, however, this article looks at utterances that are directed at specific issues, and not at general statements of discontent. This calls for reflection on another point that Szczerbiak and Taggart deemed necessary of critical evaluation; namely that 'opposing only one or two EU policy areas is clearly not sufficient to qualify a party as Eurosceptic' (Ibid.: 249). Regarding this critique, my counterargument is that it is exactly the policy level that is relevant to look at, for this is where the definition becomes useful also for practitioners. Labelling a party as soft Eurosceptic allows for the general identification of the attitude of a party towards the European Union, but it is that party's (Eurosceptic) attitude towards specific policy areas that captures the potentiality of issues to be contentious in the debates on the national and EU level.

Having established that Fidesz can be considered Eurosceptic on several and attitudinal substantive grounds, the following section goes beyond this definitional debate and looks at the consequences of a Eurosceptic party in government; in the case of Hungary, a single party with very extensive legislative and executive competences due to its (close to) supermajority in Parliament.

\section{A spatial theory of policy influence}

The influence of party Euroscepticism in government can be analysed by looking at the party strategy of a given party and how it approaches EU policies. Here we look at the party strategy of Fidesz regarding the EU, specifically the strategy in dealing with other Eurosceptic parties. Bonnie Meguid's spatial theory of party competition will be used to look at the strategy of Fidesz in reaction to the electoral success of Jobbik.

3 In September 2018, the majority of the European Parliament voted in favour of the Sargentini Report the report evaluates the state of the rule of law in Hungary and concludes that punitive actions are to be initiated against Hungary. The Hungarian Government offered a 109-paged rebuttal, where it offers their position on the different issues of the report. The report is a European document that focuses on the democratic developments in a member state. However, the motivation for the European Parliament to draft a report on the developments concerning the rule of law in Hungary was 'the existence of a clear risk of a serious breach by Hungary of the values on which the Union is founded' (Sargentini 2018). 
Meguid's spatial theory considers the political aim of mainstream parties to be the electoral loss or electoral elimination of niche parties that compete for the same or ideologically similar voters. The model comprises of three dimensions that shape the success of the mainstream party in dealing with the niche party, namely issue ownership, issue salience and policy convergence. As shown in table 1, Meguid elaborates three distinct party strategies for mainstream parties to react to the electoral success of niche parties; there are the dismissive, accommodative and adversarial strategies.

In the case at hand, the expectation is that Fidesz has been adopting an accommodative strategy towards Jobbik, since earlier research has shown a policy convergence of Fidesz towards the position of Jobbik on a number of policy areas (e.g. Krekó - Enyedi 2015). When an accommodative strategy has been used successfully, the salience of the issue at hand will increase relative to the period before the mainstream party started to compete on the issue, there will be a policy convergence of the mainstream party towards the niche and the ownership of the issue will be transferred from the niche party to the mainstream party. This would then result in a decrease in electoral support for the niche party.

Table 1: Predicted effects of mainstream party strategies

\begin{tabular}{|c|c|c|c|c|}
\hline \multirow{2}{*}{ Strategies } & \multicolumn{3}{|c|}{ Mechanism } & \multirow{2}{*}{$\begin{array}{l}\text { Niche party } \\
\text { electoral } \\
\text { support }\end{array}$} \\
\hline & Issue salience & Issue position & Issue ownership & \\
\hline Dismissive & Decreases & No movement & No effect & Decreases \\
\hline Accommodative & Increases & Converges & $\begin{array}{l}\text { Transfers to } \\
\text { mainstream party }\end{array}$ & Decreases \\
\hline Adversarial & Increases & Diverges & $\begin{array}{l}\text { Reinforces niche } \\
\text { party's ownership }\end{array}$ & Increases \\
\hline
\end{tabular}

Source: Meguid 2005: 350

The following section will test whether Fidesz indeed adopted an accommodative strategy, and whether this strategy delivered the desired results.

\section{The policy influence of Jobbik}

It is known that Jobbik's policy positioning has had a contagious effect on Fidesz's policies. Krekó and Enyedi (2015) argue that on a number of occasions Jobbik has served as a testing ground for new right-wing policy approaches; like Jobbik's vocal support of far-reaching restrictions on immigration and their 'opening to the East' (Enyedi - Róna 2018: 263). What kind of a party is Jobbik though? 
Jobbik first entered parliament in 2010 as a far-right and anti-European party, with a xenophobic and antisemitic agenda which far-right parties like Front National in France and PVV in the Netherlands even refused to cooperate with (Hebel - Schmitz 2013). In the first years, its position regarding the European Union was that of a hard Eurosceptic party that fits the categorisation of Taggart and Szczerbiak: the rejection of Hungary's membership in the EU and the conception that membership to the EU has been detrimental for Hungary and the Hungarians. In the words of Styczyńska: 'Jobbik is anti-European, and subscribes to an identity- and economy-based Euroscepticism, rejecting the very idea of European integration and the European project' (2018: 146). It has grown out to become the second largest party in the Hungarian parliament in the general elections of 2018 , receiving $19.06 \%$ of the votes.

While Fidesz does not reject Hungary's membership in the EU, the positions of Fidesz and Jobbik have been converging on the broader topic of the EU. Particularly the political and policy developments since 2015 surrounding migration policy show the contagion effect of Jobbik on Fidesz. Of the two most salient issues in migration policy in Hungarian politics - the rejection of the migrant quota scheme and the Stop Soros legislative package - both cases saw policy positions of Jobbik subsequently adopted by the Fidesz government.

Following the turbulent times of the migration crisis, with a stark increase in the amount of migrants flowing into the European Union, the European Council voted in favour - by a qualified majority - of the European Commission's proposal for the implementation of a mandatory migration scheme meant to ease the migratory pressures in Greece, Italy and Hungary (Council Decision 2015/1601). Specifically, the Commission's proposal of 9 September 2015 focused on the relocation of 160,000 people 'in clear need of international protection from Italy $(15,600)$, Greece $(50,400)$ and Hungary $(54,000)$. The relocation would be done according to a mandatory distribution key using objective and quantifiable criteria ( $40 \%$ of the size of the population, $40 \%$ of the GDP, $10 \%$ of the average number of past asylum applications, $10 \%$ of the unemployment rate)' (European Commission 2015). Hungary, along with the Czech Republic, Romania and Slovakia, vehemently rejected this proposal. Prime Minister Orbán spoke of the migration policy of the EU as a 'left-wing conspiracy against Europe', whereby the daily inflow of thousands of migrants into Europe serves as a deliberate construction that needs the government to turn to 'the people' [in order to stop it] (Orbán 2015). Jobbik response to the Council Decision was that Hungary should focus on the protection of Hungary's borders, not of Europe's borders (Jobbik 2015).

One of the Hungarian government's decisions was to call for a referendum on the migrant quota system in 2016, subsequently held on 2 October 2016. On 9 May of that year a parliamentary debate took place on the topic of a referendum on the migrant quota scheme, where Jobbik voted in favour of the 
referendum. However, in that same debate then-Jobbik leader Gábor Vona told Prime Minister Orbán that his party had proposed a referendum on the migrant quota scheme back in 2015 (Vona 2016), an idea that dates back to May 2015 (Vona 2015). Back then, Jobbik's proposal for a referendum on the migration quota scheme was rejected by Fidesz caucus leader Lajos Kósa. In October 2015, Kósa argued that such a topic is not suitable for a referendum, since Hungary is bound by international treaties (Mandiner 2016a). In order to overcome this legal hurdle, Jobbik proposed a constitutional change that would make a referendum on issues to which Hungarian has international obligations possible on 23 February 2016 (Vona - Apáti - Kárpát 2016). It was the next day that the Prime Minister announced that a referendum would take place (Mandiner 2016b).

Jobbik's policy position on the migrant scheme seems to have played a formative role in the decision-making process of Fidesz. While the party initially considered a referendum to be at odds with international treaties, months later the Hungarian government took issue ownership of the issue of the referendum.

The second policy item where the Jobbik appears to have been an influential actor in shaping the government's position is on the Stop Soros legislative package, introduced in 2018. The legislative package criminalises the assistance, by persons or organisations, of undocumented immigrants. The official motivation for this legislative package is in 'order to create common social responsibility', and therefore organisations supporting migrants are 'obliged to pay an immigration financing duty if it receives any financial or property benefit either directly or indirectly from abroad' (Hungarian Helsinki Committee 2018). The legislative package was the next step following the 2017 National Consultation on the Soros Plan - a questionnaire sent to every Hungarian citizen containing seven statements related to migration and whether they agree with those statements. ${ }^{4}$ In legislative document T19776, the government argues that the results of the consultation show that the Hungarians want 'strong border protection and decisive action against those organising and facilitating illegal immigration. Hungarian citizens unanimously reject all plans facilitating and encouraging immigration. Hungarians do not wish Hungary to become an immigration country' (Hungarian Helsinki Committee 2018).

However, the criminalisation of immigration was not a new idea. It was in 2016 that Jobbik Mayor Toroczkai decided to press charges against NGOs that were supporting immigrants illegally, and that were receiving 'billions of HUF from abroad' while 'these organizations operated with a complete lack of transparency [in 2015], deceiving the Hungarian authorities' (Jobbik 2016).

4 For instance, question two stated that 'Together with officials in Brussels, George Soros is planning to dismantle border fences in EU Member States, including in Hungary, to open the borders for immigrants' (Novak 2017). 
Toroczkai claimed that Open Society Foundations, founded by George Soros, was one such organisation that illegally gave aid to immigrants (Alfahír 2016). Toroczkai's attack on NGOs is likely to have triggered Fidesz to pick the issue and attempt to take issue ownership of it. The products of this attempt were the Soros Plan National Consultation and the subsequent Stop Soros legislative pack.

As can be seen in table 2, the results of the accommodative party strategy of Fidesz towards Jobbik regarding migration policy are mixed. First, the issue salience of migration policy has been very high in Hungarian politics since 2015 and was a salient issue in the 2018 general elections and the EP elections of 2019. Second, the positioning of both parties on the issue of migration has converged significantly. Fidesz seems to have been inspired by Jobbik to initiate the national consultation on the Soros Plan in 2018 and the referendum on the migrant quota scheme in 2016. The results for the third dimension, issue ownership, are less obvious though.

Jobbik successfully managed to take issue ownership of nationalist issues when it entered politics in the late 2000s and has continued to defend that ownership since then (Pytlas 2016). Fidesz did manage to claim some ownership in the above two cases. Firstly, Jobbik voted in favour of the government's decision to hold a referendum, which Fidesz framed as being their own idea (Bíró-Nagy 2018). Secondly, the Stop Soros legislative package is likely to have been inspired by Jobbik's mayor Toroczkai, but was introduced quite a bit later, and was also presented as an original plan by Fidesz.

Table 2: Results of Fidesz's accommodative party strategy

\begin{tabular}{|l|l|l|l|l|}
\hline & Issue salience & Issue position & Issue ownership & $\begin{array}{l}\text { Change electoral } \\
\text { support of niche } \\
\text { party (2014-2018) }\end{array}$ \\
\hline $\begin{array}{l}\text { Fidesz/Jobbik } \\
\text { migration policy }\end{array}$ & Remained high & Convergence & Partial & $\begin{array}{l}-1.16 \% \\
\text { (from 20.22\% } \\
\text { to } 19.06 \%)\end{array}$ \\
\hline
\end{tabular}

Source: author's own findings, based on Meguid (2005)

Interestingly though, the electoral loss of Jobbik in the period 2014 to 2018 was relatively insignificant, with a net loss of $1.16 \%$. Meguid's spatial theory therefore does not seem to give a complete picture in the case at hand, and other conditions might be needed to trigger the electoral loss of the niche party. One factor that appears to dampen the impact of Fidesz's accommodative strategy are the diverging concerns of their voter base.

A survey of voter concerns across partisan lines shows that the priorities of Jobbik and Fidesz voters are different (Boros and Laki 2018). While voters of both parties consider uncertainty about their future to be the most concerning, Fidesz voters are more worried about migration (second place) than Jobbik 
voters (fourth place). For Jobbik voters their financial situation and the risk of diseases are considered bigger threats than migration. Furthermore, much of Jobbik's political campaigning is directed at Fidesz and corruption scandals involving Fidesz. These factors might help to explain the limited electoral losses of Jobbik, despite the policy convergence of Fidesz towards Jobbik's position and the high salience of migration policy.

When looking at the above two cases, some points can also be made as regards the Euroscepticism of Fidesz and its relationship with the European Union. Jobbik's idea of a referendum on the migration quota system turned out to have a contagious effect on Fidesz and drew a bigger wedge between Hungary and the EU, because the Hungarian government used the result of the referendum ${ }^{5}$ to legitimise its continued rejection of the migrant quota system, despite the political isolation that followed.

Furthermore, the Stop Soros legislative package took on a European character when the European Commission initiated infringement procedures in 2018 and decided to refer Hungary to the Court of Justice of the European Union in July 2019 (European Commission 2019). This put further strain on the relationship between the European Commission and the Hungarian government.

\section{Conclusion}

Whether Fidesz should be considered (soft) Eurosceptic or not, has also been the subject of debate and disagreement. However, by looking at Euroscepticism on a policy-level rather than a party-level and upon a strict reading of position on several EU-related policy domains, this article offers a more detailed description of Fidesz's approach to the EU. The following quote captures the Hungarian government party's general behaviour towards the EU well: 'For Orbán, the goal is no longer to keep the EU out of domestic Hungarian affairs, it is to subject it to Orbán's vision; not to get the EU leadership to finally leave him (Hungary, as he terms it) alone but to replace them with people like Orbán' (Győri et al. 2018: 37).

Fidesz uses three rhetorical arguments to defend its approach towards the EU. Firstly, and specifically on the topic of migration, is the existential threat that the majority's approach towards migration poses on the future of Europe. Mass migration would damage Europe's Christian values and erode its heritage. Secondly, Fidesz cautions for the risk that transfers of competences have on people's support for the EU. It utilises the populist argument that the bureaucratic elites have lost touch with the people, while they do listen to the Hungarian people. Therefore, an attack on the Hungarian government is framed as an

5 In fact, the results of the referendum were invalid, because the voter turnout was below the threshold of $50 \%$. 
attack on the Hungarian people. A second argument to be against the transfer of competences is that it is 'a matter of sovereignty', as State Secretary Völner argued in the case of the opposition to the establishment of the European Public Prosecutor's Office. Thirdly, as the quote by Győri et al. captures, the aim of Fidesz is to change the EU from within.

On the policy-level the specific policy domains where Fidesz has a Eurosceptic position are migration policy, employment policy, fiscal policy, the creation of a European Public Prosecutor's Office, the Energy Union and Hungary's Russian and China policy (part of CFSP) are policy areas. In the case of CFSP, despite officially valuing CFSP highly, the actual political decisions of the Hungarian government towards China and Russia are obstructing a unified EU position on controversial developments in those countries.

In the last section, a spatial theory was used to show Fidesz's policy strategies regarding the EU-related dimensions of migration and showed that policy proposals of Jobbik were adopted to transfer issue ownership of these issues to Fidesz. Jobbik's succeeded in the election after Fidesz adopted an accommodative strategy to take voters away from Jobbik had largely failed, probably as a consequence of the principled opposition of Jobbik voters against the dominance of Fidesz in Hungarian politics.

Concluding, there is a kind of inverted soft Euroscepticism that characterises Fidesz's vision and policies towards the EU. The vision of Fidesz is captured by Minister of Justice Judit Varga. Reacting to criticisms coming from the EU about the rule of law in Hungary and Hungary's EU policies, she summarised the government position as follows: 'When they come up with this mantra that we are destroying Europe and are dismantling European values, I always warn them that for us European values are so important that not only did we give our blood and lives for them for centuries, but we are also proud that we can lay this down in our national avowal. This says all that needs to be said about our approach to the European project' (Government of Hungary 2019b). For an EU member state that has been the largest net per capita beneficiary of EU funds, the Fidesz government has been particularly outspoken and Eurosceptic, seeing how far it can go within the confines the EU.

\section{References}

Ágh, Attila (2013): The triple crisis in Hungary. The „Backsliding" of Hungarian Democracy after Twenty Years. Romanian Journal of Political Science 13(1): 25-51.

Alfahír.hu (2015): „Elindult a Jobbik aláírásgyűjtése a bevándorlás és korrupció ellen“ [Jobbik's petition against migration and corruption has begun]. Alfahír.hu. Available at: https:// alfahir.hu/elindult_a_jobbik_alairasgyujtese_a_bevandorlas_es_korrupcio_ellen (15 October 2019). 
Bátory, Agnes (2008): Euroscepticism in the Hungarian Party System: Voices from the Wilderness?, in Szczerbiak, Aleks - Taggart, Paul, eds., Opposing Europe? The Comparative Party Politics of Euroscepticism Volume 2 Comparative and Theoretical Perspectives, 263-276, Oxford University Press.

Batory, Agnes (2015): Populists in government? Hungary's "system of national cooperation". Democratization 23(2): 283-303.

BBC News (2014) Hungary PM Orban condemns EU sanctions on Russia, BBC News (15 August 2014), available at: https://www.bbc.com/news/world-europe-28801353 (5 August 2019).

Bíró-Nagy, András. (2018): „Politikai lottóötös: a migráció jelentősége a magyar politikában, 2014-2018“ [Political lucky lottery: the menaing of migration in magyarian politics, 2014-2018] (Böcskei B., Szabó, A. (eds.) Várakozások és valóságok: Parlamenti választás 2018. MTATKPTI, 269-291.

Boros, Tamás - Laki, Gergely (2018): A Magyar Rémálom [The Hungarian Nightmare]. Friedrich-Ebert-Stiftung - Policy Solutions.

Csehi, Robert (2019): Neither episodic, nor destined to failure? The endurance of Hungarian populism after 2010, Democratization 26(6): 1101-1027.

Duro, József (2016): Becoming Mainstream? Euroscepticism Among Established Parties in V4 Countries. Eurasian Journal of Social Sciences 4(4): 35-47.

Elmer, Keegan (2018): ‘EU Presents (Nearly) United Front Against China's 'Unfair' Belt and Road Initiative', South China Morning Post (Hong Kong) (20 April 2018), available at: https://www. scmp.com/news/china/diplomacy-defence/article/2142698/eu-presents-nearly-united-front-against-chinas-unfair (5 August 2019).

Enyedi, Zsolt - Róna, Dániel (2018): Governmental and Oppositional Populism. Competition and Division of Labour, in Wolinetz, Steven - Zaslove, Andrej, eds., Absorbing the Blow. Populist Parties and their Impact on Party and Party Systems, 251-272, ECPR Press.

European Commission (2015): „Refugee Crisis: European Commission takes decisive action“. Available at: https://europa.eu/rapid/press-release_IP-15-5596_en.htm (27 August 2019)

European Commission (2019): Press Release: „Commission takes Hungary to Court for criminalising activities in support of asylum seekers and opens new infringement for non-provision of food in transit zones." Available at: https://ec.europa.eu/commission/presscorner/detail/ EN/IP_19_4260 (14 October 2019).

European Council of Foreign Relations (2018): EU Coalition Explorer. Available at: https://www. ecfr.eu/page/ECFR269_EU_COALITION_EXPLORER_2018_V1. 10. pdf (4 November 2019).

European Union (2010): Consolidated version of the Treaty of European Union. Official Journal of the European Union, 30(2010), p. C83, available at:

https://eur-lex.europa.eu/legal-content/EN/ALL/?uri=OJ\%3AC\%3A2010\%3A083\%3ATOC

France24 (2018): 'Hungary's Orban denounces EU sanctions on Moscow', France24 (15 July 2018), available at: https://www.france24.com/en/20180715-hungarys-orban-denounces-eu-sanctions-moscow (5 August 2019). 
Göncz, Borbála - Lengyel, György (2016): Changing attitudes of Hungarian political elites towards the EU (2007-2014). Historical Social Research, 41(4): 106-128.

Gotev, Georgi (2015): ‘Orbán says EU's Energy Union is a threat to Hungary', Euractiv.com (2 February 2015), available at:

https://www.euractiv.com/section/energy/news/orban-says-eu-s-energy-union-is-a-threat-to-hungary/ (5 August 2019).

Government of Hungary (2017): 'Summary of the questions relating to the National Consultation.', available at: http://www.kormany.hu/download/5/be/01000/NK_2017_A4_v05_engl. pdf (31 January 2019)

Government of Hungary (2019a) 'The Belt and Road Initiative coincides with Hungarian national interests,' available at: https://www.kormany.hu/en/the-prime-minister/news/the-belt-and-road-initiative-coincides-with-hungarian-national-interests (16 August 2019)

Government of Hungary (2019b) 'Hungarians defend, not dismantle Europe's values,' available at: https://www.kormany.hu/en/ministry-of-justice/news/hungarians-defend-not-dismantle-europe-s-values (16 August 2019)

Gricius, Gabriella (2019): Hungary's Relationship with Russia Poses a Risk for Europe, Global Security Review (30 March 2019), available at: https://globalsecurityreview.com/hungarys-growing-relationship-russia/ (5 August, 2019).

Győri, Gábor, - Bíró-Nagy, András - Sebők, Miklós (2018): Hungarian Politics in 2018, Friedrich-Ebert-Stiftung and Policy Solutions, available at: https://www.policysolutions.hu/userfiles/ Hungarian_Politics_in_2018_web.pdf

Hargitai, Tibor (2018): Redefining Euroscepticism. Köz-gazdaság, XIII(3): 99-110.

Hebel, Christina - Schmitz, Gregor. P. (2013): 'Euroskeptic Union. Right-Wing Populists Forge EU Alliance'. Spiegel Online (Online). Available at: http://www.spiegel.de/international/europe/ wilders-and-le-pen-plan-right-wing-populist-faction-in-eu-parliament-a-933340.html (Accessed on 4 February, 2019).

Hungarian Helsinki Committee (2018): Translation Bills-T19776-T19774-T19775. Hungarian Parliament. Available at: https://www.helsinki.hu/wp-content/uploads/Stop-Soros-package-Bills-T19776-T19774-T19775.pdf (5 November 2019).

Jobbik (2015) „Jobbik: Name Those Responsible For Migration Crisis!“ Jobbik.hu. Available at: https://www.jobbik.com/jobbik_name_those_responsible_for_migration_crisis (2 September 2019).

Jobbik (2016): „Enough is Enough! Toroczkai presses charges against illegally operating aid.“ Jobbik.hu. Available at: https://www.jobbik.com/enough_is_enough_toroczkai_presses_ charges_against_illegally_operating_aid_organizations (2 September 2019).

Keukeleire, Stephan - Delreux, Tom (2014): The Foreign Policy of the European Union. New York: Palgrave Macmillan.

Kochenov, Dimitry - Bárd, Petra (2018): Against overemphasizing enforcement in the crisis: EU law and the rule of law in the (new) member states, in Matlak, Michael - Schimmelfennig, Frank - Wozniakowski, Tomasz P., eds., Europeanization revisited: Central and Eastern Europe in the European Union, 72-89. European University Institute. 
Kopecky, Petr - Mudde, Cas. (2002): The Two Sides of Euroscepticism: Party Positions on European Integration in East Central Europe. European Union Politics 3(3): 297-326.

Krekó, Péter - Enyedi, Zsolt (2015): Transforming Hungary - together? in Minkenberg, Michael (ed.) Transforming the Transformation?, The East European Radical Right in the Political Process, 183-205, Routledge.

Mandiner.hu (2016a): „Kósa: Nem lehet a migránskvótáról népszavazni [Kósa: It is not possible to have a referendum on the migration quota]. "Available at: https://migracio.mandiner.hu/ cikk/20160224_kosa_nem_lehet_a_migranskvotarol_nepszavazni (29 August 2019).

Mandiner.hu (2016b): „Orbán: Népszavazás lesz a migránskvótáról“ [Orbán: There will be a referendum on the migration quota system]. Available at: https://migracio.mandiner.hu/ cikk/20160224_orban_nepszavazas_lesz_a_migranskvotarol?utm_source=mandiner \& utm_ medium=link \& utm_campaign=mandiner_201910 (15 October 2019).

Martonyi, János (2014): Europe, Central Europe and Hungary: 2014, a Year of Anniversaries, Europe-Asia Studies, 3(66), 359-363.

Meguid, Bonnie M. (2005): Competition Between Unequals: The Role of Mainstream Party Strategy in Niche Party Success. American Political Science Review 93(3): 347-359.

Meguid, Bonnie M. (2008): Party competition between unequals: Strategies and electoral fortunes in Western Europe, Cambridge University Press.

Ministry of Foreign Affairs of Hungary (2012) Hungary's National Security Strategy 2012. Available at: https://www.eda.europa.eu/docs/default-source/documents/hungary-national-security-strategy-2012.pdf (11 December 2019).

Novak, Benjamin (2017) „Here are the "Soros Plan“ national consultation questions!“ Budapest Beacon. Available at: https://budapestbeacon.com/soros-plan-national-consultation-questions/ (5 November 2019).

Orbán, Viktor (2015a): 'Prime Minister Viktor Orbán's interview on Kossuth Rádió's „180 minutes“ programme', 19 September. Available at: https://www.kormany.hu/en/the-prime-minister/ the-prime-minister-s-speeches/prime-minister-viktor-orban-on-kossuth-radio-s-180-minutes (4 November 2019).

Orbán, Viktor (2015b): 'Prime Minister Viktor Orbán's interview on Kossuth Rádió's „180 minutes" programme', 24 November. Available at: https://www.kormany.hu/en/the-prime-minister/ the-prime-minister-s-speeches/prime-minister-viktor-orban-s-interview-on-kossuth-radio-s180-minutes-programme20151124 (4 November 2019).

Orbán, Viktor (2016): 'Speech by Prime Minister Viktor Orbán on 15 March'. Available at: https:// www.kormany.hu/en/the-prime-minister/the-prime-minister-s-speeches/speech-by-prime-minister-viktor-orban-on-15-march (26 August 2019).

Orbán, Viktor (2019a): 'Viktor Orbán's press conference at the 127th Government Info', available at: http://www.kormany.hu/en/the-prime-minister/the-prime-minister-s-speeches/viktor-orban-s-press-conference-at-the-127th-government-info (31 January 2019).

Orbán, Viktor (2019b): ‘Prime Minister Viktor Orbán's speech at the 30th Bálványos Summer Open University and Student Camp, 27 July', available at: https://www.kormany.hu/en/the- 
-prime-minister/the-prime-minister-s-speeches/prime-minister-viktor-orban-s-speech-at-the30th-balvanyos-summer-open-university-and-student-camp (5 August, 2019).

Orenstein, Mitchell A. - Kelemen, Daniel R. (2017): Trojan Horses in EU Foreign Policy, Journal of Common Market Studies, 55(1), 87-102.

Procházka, David - Cabada, Ladislav (2020): Exploring the "grey zone“: The Theory and Reality of "Hybrid Regimes" in Post-Communistic Countries. Journal of Comparative Politics 13(1): 4-22.

Pytlas, Bartek (2016): Radical Right Parties in Central and Eastern Europe. Mainstream party competition and electoral fortune. Routledge.

Rogán, Antal - Gulyás, Gergely - Kocsis, Máté (2013): ‘H|11729 a Magyarországot megillető egyenlő elbánásról [on equal treatment for Hungary'. Országgyülés Hivalata. Available at: https://www.parlament.hu/irom39/11729/11729.pdf (4 November 2019).

Sargentini, Judith (2018): 'Report on a proposal calling on the Council to determine, pursuant to Article 7(1) of the Treaty on European Union, the existence of a clear risk of a serious breach by Hungary of the values on which the Union is founded $(2017 / 2131(\mathrm{INL}))^{\prime}$, available at: http://www.europarl.europa.eu/sides/getDoc.do?pubRef=-//EP//TEXT+REPORT+A8-20180250+0+DOC+XML+V0//EN \& language=en (31 January 2019)

Sedelmeier, Ulrich (2014): Anchoring Democracy from Above? The European Union and Democratic Backsliding in Hungary and Romania after Accession, Journal of Common Market Studies, 52(1), 105-121.

Styczyńska, Natasza (2018): Eurosceptic parties in the Central and Eastern European Countries. A comparative case study of Poland, Hungary and Bulgaria, inLeruth, Benjamin - Startin, Nicholas - Usherwood, Simon, eds., The Routledge Handbook of Euroscepticism, 139-154, Routledge.

Szczerbiak, Aleks - Taggart, Paul (2008): Opposing Europe? The Comparative Party Politics of Euroscepticism Volume 2 Comparative and Theoretical Perspectives, Oxford University Press.

Szczerbiak, Aleks - Taggart, Paul (2017): Contemporary research on Euroscepticism: the state of the art, in Leruth, Benjamin - Startin, Nicholas - Usherwood, Simon, eds., The Routledge Handbook of Euroscepticism, 11-21, Routledge.

Taggart, Paul - Szczerbiak, Aleks (2002): The Party Politics of Euroscepticism in EU Member and Candidate States. European Consortium for Political Research Joint Workshops

Taggart, Paul - Szczerbiak, Aleks (2013) Coming in from the Cold? Euroscepticism, Government Participation and Party Positions on Europe, Journal of Common Market Studies, 51(1): 17-37.

Than, Krisztina (2019): 'Hungary rejects rule-of-law criteria for EU funding -minister', Reuters (24 July 2019), available at: https://uk.reuters.com/article/uk-hungary-justice-minister/hungary-rejects-rule-of-law-criteria-for-eu-funding-minister-idUKKCN1UJ1R8 (18 December 2019).

Thorpe, Nick (2019): 'Hungary Orban: Europe's centre-right EPP suspends Fidesz' BBC News [online] (20 March 2019), available at: https://www.bbc.com/news/world-europe-47622921 (1 August 2019).

Treib, Oliver (2014): The voter says no, but nobody listens: causes and consequences of the Eurosceptic vote in the 2014 European elections, Journal of European Public Policy (July): 1-14. 
Várnagy, Réka (2014): Hungary, in Conti, Nicolò, ed., Party attitudes towards the EU in the Member States: Parties for Europe, parties against Europe, 174-189, Routledge.

Végy, Zsuzsanna (2019): ‘Hungary for more: Viktor Orbán's new European battles.' ECFR.eu (13 February, 2019), available at: https://www.ecfr.eu/article/commentary_hungary_for_more_ viktor_orbans_new_european_battles (15 August 2019)

Völner, Pál (2019): 'Answer on 2 April 2019 to written question of Dr. Tóth Bertalan (MSZP), VII-PF/40/2/2019' Hungarian Parliament, available at: https://www.parlament.hu/ irom41/05356/05356-0001.pdf (1 August 2019).

Vona, Gábor (2015): „Vona7 - Népszavazás a bevándorlás ügyében.“ [Vona7-A referendum on the migration issue.] YouTube.com. Available at: https://www.youtube.com/watch?v=t5mQZ2xAzlA (15 October 2019).

Vona, Gábor (2016): „Országgyűlési Napló, 24397 [Daily Proceedings of the Parliament, 24397]." Parlament.hu Available at: https://www.parlament.hu/documents/10181/56618/ ny160509/3eff508c-02b4-4508-ab49-02dbb769e925 (6 September 2019)

Vona, Gábor - Apáti, István - Z. Kárpát, Dániel (2016): „Magyarország Alaptörvényének hatodik módosításáról, T|9256, [For a sixth change of the Fundamental Law of Hungary, 23 February 2016]." Available at: https://www.parlament.hu/irom40/09256/09256.pdf (15 October 2019).

Tibor Hargitai is a PhD candidate of International Relations at the Corvinus University of Budapest, Hungary. Email address: tiborhargitai22@gmail.com 